\title{
MASS Claims UNDER ICSID
}

\author{
KATARZYNA BARBARA SZCZUDLIK *
}

\section{INTRODUCTION}

In any mass claim proceedings it is a daunting task for the judicial body to correctly balance "the tension between individualized justice (...) and efficiency and speed" ${ }^{\prime}$. And for a number of reasons this struggle is even more self-evident in investment arbitration.

The heat has been turned up recently in the debate concerning mass claims arbitration, particularly after thousands of Italian bondholders brought a case against Argentina at the International Centre for Settlement of Investment Disputes ("ICSID"). This was followed shortly afterwards by two other mass claims proceedings, and it is very likely that the international arbitration environment will witness further attempts to initiate mass proceedings. This is why the topic merits closer analysis.

Is the international investment claims system well-suited to deal with mass claims? Issues arising concern the consensual nature of arbitration, the adequacy of the Convention on the Settlement of investment Disputes between States and Nationals of Other States (hereinafter "ICSID Convention") ${ }^{2}$ and the Rules of Procedure for Arbitration Proceedings (hereinafter "ICSID Arbitration Rules") ${ }^{3}$ to address issues that emerge during mass claims proceedings, as well as due process considerations, which are particularly likely to occur when a tribunal resorts to the sorts of techniques typically employed by international commissions and tribunals in mass claims ${ }^{4}$.

While class arbitration could be, at least in theory, initiated in numerous fora, this paper restricts itself to ICSID investment arbitration. The

DOI: $10.1515 /$ wrlae-2015-0016

*Advocate trainee at Warsaw Bar (Poland), LL.M. (University of Wroclaw), LL.M., with distinction (Tilburg University), LL.M. (MIDS - Master in International Disputes Settlement, IHEID/University of Geneva). The author in this article presents its private opinions that do not belong to any firm or institution with which the author cooperates.

${ }^{1}$ Hans Das, 'The Concept of Mass Claims and the Specificity of Mass Claims Resolution' in The International Bureau of the Permanent Court of Arbitration (eds), Redressing Injustices Through Mass Claims Processes. Innovative Responses to Unique Challenges (Oxford University Press 2006) 5.

${ }^{2}<$ https://icsid.worldbank.org/ICSID/StaticFiles/basicdoc/CRR English-final.pdf $>$ accessed 13 November 2015.

${ }^{3}<$ https://icsid.worldbank.org/ICSID/StaticFiles/basicdoc/CRR English-final.pdf $>$ accessed 13 November 2015

${ }^{4}$ See Chapter II below. 
reason is simple - discussions on this subject visibly accelerated after ICSID tribunals issued arbitral awards.

\section{MASS CLAIMS ${ }^{5}$ - OVERVIEW}

\section{Introduction}

First, we need to examine what motivates mass claims and why some legal systems accommodate them. There are multiple rationales for mass claims, mostly related to efficiency. However, many states have not decided to allow them, citing numerous drawbacks, mostly of a procedural nature, for both claimants and respondents.

ICSID arbitration tribunals have no experience in conducting mass proceedings. In contrast, there is abundant practice with mass claims at domestic courts, arbitral tribunals, international courts and claims commissions. This chapter provides an overview of the existing legal environment, where mass claims have existed for some time, and which may prove instructive when assessing the approach of ICSID tribunals.

\section{Representative and aggregate proceedings - differences}

Proceedings involving multiple claimants are not homogenous. In this large group we may point out two main types: representative and aggregate proceedings. There is a key difference between them. The most important type of the former is the class action suit. Class actions can be initiated by a member of a class on behalf of the whole class, or by an agent. The key feature here is that in the end there is one claim, but with many, or even a mass of claimants. There is a presumption that a representative acts on behalf of the whole class of claimants, who are automatically bound by the award of the court/tribunal ${ }^{6}$.

Aggregate proceedings involve several separate and individual claims that have the same fact pattern as their basis. This type of procedure exists in the UK, where a common registry is created and a common judge assigned to those similar cases, as well as in the US, where claims are consolidated only at the pre-trial stage - as a result, during this initial phase a court may benefit from economies of scale. After that, each case is dealt with separately, both as to liability and/or damages". In the aggregate procedure "plaintiffs must 'opt in' or intervene in the lawsuit, in order to be bound" 8 . Therefore it is up to a claimant to express his willingness to have a judgment applicable to him.

\footnotetext{
${ }^{5}$ For the purpose of this paper "mass claim" means any proceedings initiated by a class of claimants together or by a single claimant (group of claimants) on behalf of the whole class, unless expressly specified otherwise, see for example Maciej Zachariasiewicz, 'Kilka refleksji w odniesieniu do możliwości rozwoju postępowań grupowych w arbitrażu w Polsce' (2014) 1(25) ADR. Arbitraż i mediacja 65.

${ }^{6}$ Zachariasiewicz, Kilka refleksji (n 6) 70. Note that in general in Europe it is not acceptable that a claimant who neither file a suit nor join mass clam proceedings is bound by an arbitral award issued in such proceedings, see ibid 70.

${ }^{7}$ Stacy I. Strong, 'From Class to Collective: The De-Americanization of Class Arbitration' (2010) 26 Arbitration International 504.

${ }^{8}$ Veijo Heiskanen, “Arbitrating Mass Investor Claims: Lessons of International Claims Commissions" in Permanent Court of Arbitration (eds), Multiple party actions in international arbitration (Oxford University Press 2009) 298.
} 
There is no joint dealing with the cases: the aggregate element, at least in the US and UK exists only at the pre-trial stage. During the actual proceedings cases are treated as separate.

\section{Mass claims in various legal systems}

\subsection{Mass claims in American law}

Countries differ in many respects when it comes to the legal framework applicable to mass claims. A comparative overview of those regulations lies outside the scope of this paper. However, it is worth taking a look at the American system, to illustrate one possible approach to the issue under national law?.

US class action litigation is regulated by Rule 23 of the Federal Rules of Civil Procedure (hereinafter "Fed. R. Civ. Proc." "Federal Rules") ${ }^{10}$. Rule 23.a.of the Federal Rules lays down the tests to be met for bringing a mass claim. One test is that there are too many claimants to make joinder of their cases practicable. Another requires the existence of legal or factual questions common for the whole class of claimants ${ }^{11}$. In addition, a claim brought by a representative of a class has to be typical for the whole class ${ }^{12}$. Lastly, representatives shall ensure fair and adequate protection of the interests of the whole class ${ }^{13}$. A class action in the form specified by the Federal Rules is therefore a representative type, which means that the decision rendered by a court in a case initiated by a representative is binding upon the whole class. However, a class member may avoid this res iudicata effect by opting out of the class litigation after he is notified that a class action has been filed by a representative ${ }^{14}$.

In a US-type mass claim claimants may seek individual damages and other types of relief. But this approach, common in the US, is not accepted universally even within the US. The main problem seems to be the fact that individual damages are granted by a court in a representative action, which limits the defendant's rights - he cannot defend each individualized suit, but has to respond to a mass suit. And it may so happen that the defendant has arguments that are pertinent in a case against one individualized plaintiff, but irrelevant against another. Also, the rights of each member of a mass claim to initiate and conduct an individualized case are not fully protected ${ }^{15}$.

Controversial as it may be, this US solution adopted in the realm of mass claims seems to comply with the requirements of the due process rule ${ }^{16}$. The present consensus is apparently quite widely accepted in the US, since in addition to the federal regulation, more than $60 \%$ of states in the US have

\footnotetext{
${ }^{9}$ For a comprehensive overview of the American approach to the issue see for example Maciej Zachariasiweicz, 'Ameryki bitwa o pozwy zbiorowe w arbitrażu, czyli dramat w 7 aktach' (2013) 4 (24) ADR. Arbitraż i mediacja 79-99.

$10<\mathrm{http}: / / \mathrm{www}$. uscourts.gov/uscourts/rules/civil-procedure.pdf $>$ accessed 13 November 2015.

${ }^{11}$ Rule 23(a)(2) of Fed. R. Civ. Proc.

12 Rule 23(a)(3) of Fed. R. Civ. Proc.

${ }^{13}$ Rule 23(a)(4) of Fed. R. Civ. Proc.

${ }^{14}$ Rule 23(c) of Fed. R. Civ. Proc.

${ }^{15}$ Strong, 'From Class to Collective' (n 8) 504.

${ }^{16}$ Eric P. Tuchmann, 'The Administration of Class Action Arbitrations' in Permanent Court of Arbitration (eds), Multiple Party 325.
} 
adopted regulations that are either identical or similar to Rule 23 of the Federal Rules ${ }^{17}$.

\subsection{Mass claims in American arbitration law}

US regulation of domestic arbitration ${ }^{18}$ is a perfect example of initiation of mass claims outside state courts, since the idea of class action arbitration derives from this country ${ }^{19}$.

The American Arbitration Association's ("AAA") Arbitral Rules and AAA Supplementary Rules for Class Arbitration ("Class Rules") provide for the possibility to initiate proceedings in the name of a class of claimants by a self-selected representative. Pursuant to Art. 1 (A) of the AAA Class Rules those rules are applicable "where a party submits a dispute to arbitration on behalf of or against a class or purported class, and shall supplement any other applicable AAA rules. These (...) Rules shall also apply whenever a court refers a matter pleaded as a class action to the AAA for administration, or when a party to a pending AAA arbitration asserts new claims on behalf of or against a class or purported class".

Adoption of this rule was predated by the US Supreme Court's decision in Green Tree Financial Corp v Bazzle ${ }^{20}$. In this case, arbitration agreements contained in the relevant loan agreements did not contain any reference to class action ${ }^{21}$. The arbitrator decided in favour of the class of two claimants, and this decision was confirmed by the South Carolina courts ${ }^{22}$. Green Tree brought this case to the US Supreme Court, claiming that an interpretation of the arbitration clause that would allow bringing mass claims was incorrect since the clauses purposefully did not address class action and, as a result, there was no possibility of initiating a class action. The Supreme Court held that absent specific wording in the arbitration agreement, there is a presumption that class arbitration is allowed. It was decided that the arbitrator was given broad powers under the arbitration clause and that the arbitrator, not a court, should decide on the issue of interpretation of a contractual arbitration clause ${ }^{23}$.

This judgment had far-reaching consequences. Another court concluded that they read Bazzle as "an implicit endorsement by the majority of the Court of class arbitration procedures as consistent with the Federal

\footnotetext{
${ }^{17}$ ibid 327.

${ }^{18}$ In the margin shall be noted that United States is not the only country where class action is used in domestic arbitration - this mechanism exist also, for example, in Canada, see Dell Computer Corp. v Union des consommateurs, [2007] 2 S.C.R. 801, 2007 SCC 34; Jeffrey S. Leon et al., 'Class Arbitration in Canada: The Legal and Business Case' (2010) 6 Canadian Class Action Review, and in Colombia (see Valencia v Bancolombia (Colombia v Colombia), Zuleta Digest for Transnational Arbitration (ITA) (Arb. Trib. Bogota Chamber Comm. 2003) <www. kluwerarbitration.com> accessed 13 November 2015.

${ }^{19}$ Lukasz Gorywoda, 'Arbitraż Grupowy' (2014)3-4(14-15) e-przeglad arbitrażowy 25-6 $<$ http://www.sadarbitrazowy.org.pl/pl/eczasopisma;id-37> accessed 13 November 2015; Stacy I. Strong, 'Collective Arbitration under the DIS Supplementary Rules for Corporate Law Disputes: A European Form of Class Arbitration?’ (2011) 29 ASA Bulletin 145.

20 Green Tree Financial Corporation v Bazzle, 539 U.S. 444 (2003) $<$ http://www.supremecourts.gov/opinions/02pdf/02-634.pdf > accessed 13 November 2015.

21 Tuchmann (n 16) 327.

${ }^{22}$ Bazzle (n 20) 449.

${ }^{23}$ Bazzle (n 20) 451, 454.
} 
Arbitration $A c t, 24$. According to this Supreme Court decision, when an arbitration clause is silent on the possibility of initiating class arbitration, then class arbitration is in fact allowed.

Bazzle triggered amendments to the AAA Rules. The AAA Class Rules followed the framework adopted in Rule 23 of Fed. R. Civ. Proc. The AAA paid due attention to the way the arbitrator interprets an arbitration agreement, which is regulated in Rule 3 of the Class Rules as follows: "the arbitrator shall determine as a threshold matter, in a reasoned, partial final award on the construction of the arbitration clause, whether the applicable arbitration clause permits the arbitration to proceed on behalf or against a class".

Moreover, pursuant to Rule 3(b) of the Class Rules "in construing of the applicable arbitration clause, the arbitrator shall not consider the existence of these Supplementary Rules, or any other AAA Rules to be a factor either in favor or against permitting the arbitration to proceed as a class". Therefore, the AAA clearly indicated that the wording of the Class Rules cannot serve as an argument in favour of the automatic conclusion that every arbitration clause permits class actions.

In addition, under Rule 4 of the Class Rules, an arbitrator is obliged to ensure that a claim may be dealt with in class arbitration. The tests set forth in this provision are identical to those listed in Rule 23 of Fed. R. Civ. Proc. As a result, mass claims proceedings before an AAA tribunal/arbitrator also take the form of a "representative type",25.

Recently, further clarifications of this issue (maybe even changes) were made in Stolt-Nielsen S.A. v AnimalFeeds Int.l corp, ${ }^{26}$ and AT\&T Mobility $L L C$ v Concepcion ${ }^{27}$. In the former case, the Supreme Court decided that only explicit consent, as opposed to arbitration clauses being silent on the matter, renders mass claims arbitrable. The court held that an implicit agreement is not enough to find that class action arbitration is within the scope of parties' "regular" agreement to arbitrate. The reason for this is that arbitration in the form of class action "changes the nature of arbitration" 28 so significantly that one cannot presume that an agreement to arbitrate disputes is tantamount to the parties' implicit agreement to class action arbitration $^{29}$.

Further, according to the Supreme Court "arbitration is poorly suited" to class actions, because in those proceedings there is an increased risk for defendants and the likelihood of errors is higher, especially when damages allegedly owed to thousands of claimants are aggregated and must be decided in one fell swoop ${ }^{30}$. In addition, it was observed that since there are fundamental differences between classic, bilateral arbitration and class

\footnotetext{
${ }^{24}$ Shroyer v New Cingular Wireless Services, Inc., 498 F.3d976, 992 (9th Cir. 2007), August 17, $2007<$ http://caselaw.findlaw.com/us-9th-circuit/1525247.html> accessed 13 November 2015.

${ }^{25}$ See point 1.2. above.

${ }^{26}$ Stolt-Nielsen S.A. v AnimalFeeds International Corporation, 130 S.Ct. (2010).

${ }^{27}$ AT\&T Mobility llc v Conception, No. 09-893, 131 S. Ct. 1740 (2011).

${ }^{28}$ Underlined by the present author.

${ }^{29}$ Stolt Nielsen (n 26) 1774.

30 Antonio Crivellaro, "Third-party funding and "mass" claims in investment arbitrations" (2013) Dossier - Third Party Funding in International Arbitration (ICC DRL Library) 139.
} 
actions, one cannot "presume" consent from the parties' silence ${ }^{31}$. Furthermore, the Court held that in that case it was not necessary, and therefore the court was not obliged to assess what types of "contractual basis", i.e. contractual provisions, may be supportive of a conclusion that the parties consented to arbitrate any dispute between them in the form of a class action. Therefore this case in the end provides little support for any definite conclusion as to what particular contractual wording may mean agreement to class arbitration.

In AT\&T Mobility LLC v Concepcion it was emphasized that class arbitration exerts great influence upon the core features of arbitration and poses significant risks to defendants. The court also stressed the lack of recourse to an appeal court as to the merits after a class action arbitral award, which inevitably means that the odds of errors remaining uncorrected are higher. As a result, "the risks of error may become unacceptable when damages allegedly owed to thousands of claimants are aggregated and decided at once. Arbitration is poorly suited to these higher stakes" ${ }^{\prime 32}$. Therefore the US Supreme Court decided that consent to arbitration should be interpreted more strictly and that there is a requirement of special consent in the case of mass arbitration.

In keeping with AAA, and in the aftermath of Bazzle, another US arbitration institution adopted rules that provide for class arbitration ${ }^{33}$. There are also examples from outside the US. For example, in 2009 the German Institution for Arbitration (DIS) published rules according to which collective arbitration is possible in corporate disputes that require a decision that is binding on a company and its shareholders ${ }^{34}$. Interestingly, the DIS collective arbitration took the form of non-class proceedings, unlike the AAA class arbitration $^{35}$. Importantly, the scope of application of both DIS and AAA rules mirrors the availability of collective action before state courts, which improves domestic enforcement of class/collective arbitral awards ${ }^{36}$. It is fair to say that the "DIS has created an entirely new dispute resolution mechanism that reflects the kind of jurisprudential policies and preferences that are common in Europe ${ }^{\text {,37. }}$.

It remains to be seen how this issue will evolve in US and German domestic arbitration. For now, the fact that 352 class action arbitration cases were conducted up to October 2013 under AAA proves that this approach is viewed as necessary and has gained acceptance ${ }^{38}$. In addition, notwithstanding

\footnotetext{
${ }^{31}$ Stolt - Nielsen, Slip Opinion (n 26) 22-23.

${ }^{32}$ AT\&T Mobility LLC, Slip Opinion (n 27).

33 Judicial Arbitration and Mediation Services (JAMS) Class Action Procedures $<$ http://www.jamsadr.com/rules-class-action-procedures/> accessed 13 November 2015 .

${ }^{34}$ DIS-Supplementary Rules for Corporate Law Disputes 09 (SRCoLD) $<$ http://www.disarb.de/de/16/regeln/dis-supplementary-rules-for-corporate-law-disputes-09-srcold-id15> accessed 13 November 2015; for a comparison between DIS rules and AAA rules, see Strong, 'Collective Arbitration' (n 19).

${ }^{35}$ Strong, 'Collective Arbitration' (n 19) 148.

${ }^{36}$ ibid 150; Strong, 'From Class to Collective' (n 7) 507.

${ }^{37}$ Strong, 'Collective Arbitration' (n 19) 164.

38 American Arbitration Association, Class Arbitration Case Docket $<$ http://www.adr.org/aaa/faces/services/disputeresolutionservices/casedocket?afrLoop=415 $794185525297 \quad \&$ afrWindowMode=0\& afrld $\quad=$ ky
} 
this apparent consensus and practical workability, every jurisdiction has its own policies and interest to reconcile in class arbitration, meaning that the US experience, though instructive, will not be directly transferred to other countries $^{39}$.

\subsection{Mass claims in international law}

International mass claims have been dealt with for many years by international claims commissions and claims tribunals ${ }^{40}$. Those international bodies multiplied after World War $\mathrm{I}^{41}$. In general, they failed to perform their functions timely and effectively, resulting in this method of dispute resolution being largely abandoned after World War $\mathrm{II}^{42}$. In the relatively recent past the idea of claims commissions and tribunals has had a new lease of life, starting with the Iran-United States Claims Tribunal ${ }^{43}$. Other examples of such tribunals are the United Nations Compensation Commission, the Commission for Real Property Claims of Displaced Persons and Refugees in Bosnia and Herzegovina, the Housing and Property Claims Commission and the Claims Resolution Tribunal for Dormant Accounts in Switzerland.

All those bodies were supposed to achieve their goals in a short period of time and at lower cost compared to ordinary dispute resolution mechanisms ${ }^{44}$. Therefore, some restrictions on the normal course of litigation are inherent in their procedures, but the countries that helped set them up consented to those constraints on due process rules at the very beginning. They knew what they were doing. The efficiency of those mass litigations compared to their WWI "predecessors" has improved significantly ${ }^{45}$. To achieve this, the procedural rules of the commissions adopt an array of techniques such as computerization, forming groups of claims based upon same/similar legal and factual patterns, using "cover decisions" (deciding claims of many claimants), using evidentiary presumptions, relaxing the standard of proof and adopting statistical methods ${ }^{46}$. Tribunals and commissions were vested with the power to properly regulate issues such as management of the case and certification of the class ${ }^{47}$. A judgment obtained as a consequence of this procedure is therefore binding upon all members of a class ${ }^{48}$.

19xujik 166\#\%40\%3F afrwINDOWLD $\% 3 \mathrm{dKY} 19 \mathrm{XUJIK} 166$

$\% 26$ afrLoop $\% 3 \mathrm{D} 415794185525297 \% 26$ afrWindowMode $\% 3 \mathrm{DO} \% 26$ adf.ctrl-

state\%3Dky19xujik 211> accessed 13 November 2015.

39 Gabrielle Nater-Bass, 'Class Action Arbitration -A New Challenge?' (2009) 27 ASA Bulletin 680-689.

${ }^{40}$ For the general overview see The International Bureau of the Permanent Court of Arbitration (eds), Redressing Injustices Through Mass claims Processes (Oxford University Press 2006); Howard M. Holtzmann, Edda Kristjansdottir (eds), International Mass Claims Processes: Legal and Practical Perspectives (Oxford University Press 2007).

${ }^{41}$ Norbert Wuhler, 'Mixed Arbitral Tribunals' in I. R. Bernhardt (eds), Encyclopedia of Public International Law (Elsvier 2000) 143.

42 Heiskanen (n 8) 300 and the sources indicated therein.

${ }^{43}$ ibid 301.

${ }^{44} \operatorname{Das}(\mathrm{n} 1) 5$.

${ }^{45}$ John Crook, 'Mass claims Processes: Lessons Learned Over Twenty-Five Years' in The International Bureau of the Permanent Court of Arbitration (eds) Redressing Injustices 41, 55 .

${ }^{46}$ Heiskanen (n 8) 301-2.

47 ibid 298.

48 ibid 54. 


\subsection{Mass claims in international arbitration}

International arbitration was originally designed to resolve individual claims effectively ${ }^{49}$. Class actions, on the other hand, bring to mind lengthy proceedings involving multiple claimants whose claims are associated for the purpose of joint consideration ${ }^{50}$. There is a clear contradiction here.

Naturally, it is far from unusual for an arbitral institution to accept a request for arbitration filed by multiple claimants/respondents in group proceedings $\mathrm{s}^{51}$. However, group proceedings cannot be equated to mass claims in the version adopted by AAA, which is significantly less common for commercial arbitration worldwide. For example, unlike the domestic arbitration examples of DIS rules and AAA rules, the ICC overtly criticized the transplantation of class action to arbitration proceedings ${ }^{52}$. The issue of class arbitration in the context of competition law has also emerged at the European Union level ${ }^{53}$.

Set against this background the question arises of whether AAA class arbitration is suitable for the resolution of disputes at the international level. This issue emerged in Fellows of Harvard University $v$ Surgutneftegaz, a Russian company. It was finally decided by a US district court that the arbitration clause allowed for class arbitration ${ }^{54}$. But as a result, some scholars expressed concerns about AAA arbitral awards being a tool for the "implantation" of class actions-based awards to countries where class action as such does not exist ${ }^{55}$. Others, however, do not see any problem in the enforcement of awards rendered under US-style class arbitration ${ }^{56}$. However, the risk of this occurring is real given the obligation of the contracting states under the Convention on the Recognition and Enforcement of Foreign Arbitral Awards of 1958 ("New York Convention") ${ }^{57}$ to recognize and enforce foreign arbitral awards. At the enforcement stage it does not matter whether

\footnotetext{
${ }^{49}$ Gary B. Born, International Commercial Arbitration (Wolters Kluwer 2009) 252.

${ }^{50}$ Manual for Complex Litigation, Fourth, 10.1. (Federal Judicial Center, 2004); American Law Institute, Principles of the Law of Aggregate Litigation $<$ http://www.ali.org/index.cfm?fuseaction=publications.ppage\&node $\mathrm{id}=80>$ accessed 13 November 2015.

${ }^{51}$ Carolyn B. Lamm, Hansel T. Pham, Alexandra K. Meise Bay, 'Consent and due Process in Multiparty Investor-State Arbitrations' in Christina Binder, Ursula Kriebaum, August Reinisch, Stephan Wittich (eds), International Investment Law for the 21st Century. Essays in Honour of Christoph Schreuer (Oxford University Press 2009) 54.

52 Class Action Litigation, Document no. 460/585, December 1, 2005 $<$ http://www.iccwbo.org/Advocacy-Codes-. and-Rules/Document-centre/2005/Classaction-litigation/> accessed 13 November 2015.

${ }^{53}$ For an overview of this issue see Lukasz Gorywoda, 'The Emerging EU Legal regime for collective Redress: Institutional Dimension and Its Main Features' in Arnaud Nuys, Nikitas E Hatzimihail (eds), Cross-Border Class Action: the European Way (Sellier European Law Publishers 2014).

${ }^{54}$ ibid 335.

55 Tuchmann (n 16) 334.

${ }^{56}$ Born (n 49) 2703; Daniele Favalli, Joseph M. Matthews, 'Recognition and Enforcement of U.S. Class Action Judgements and Settlement in Switzerland' (2007) 1 Revue Suisse de Droit International et Européen 25-26; Stacy I. Strong, 'Enforcing Class Arbitration in the International Sphere: Due Process and Public Policy Concerns' (2008) 30 U. Pa. J. Int'l L 100.

${ }^{57}$ Convention on the Recognition and Enforcement of Foreign Arbitral Awards, June 10, 1958, 330 UN.T.S. 3.
} 
an award was rendered in class arbitration or whether the state of enforcement allows class action - under the New York Convention a contracting state has to enforce every arbitral award, unless the grounds for refusal contained in Art. V of the New York Convention are present. Unsurprisingly, state courts may be reluctant to agree to such transplantation.

However, future developments as to the reception of class arbitration awards worldwide are uncertain. In particular, the question arises of how a court of a European country would react to an arbitral award involving nonAmerican parties, rendered by an AAA tribunal after class action arbitration, since the legal framework that concerns class actions differs significantly between the US and Europe ${ }^{58}$. Notwithstanding all those concerns, increasing numbers of scholars advocate the spread of large-scale group arbitration outside the US ${ }^{59}$.

\section{II. "MASS CLAIMS" IN INVESTMENT ARBITRATION UNDER THE ICSID CONVENTION - CONSENT, ADMISSIBILITY OR SOMETHING ELSE?}

\section{Introduction}

Although mass claims proceedings are by no means a novelty either in litigation or in domestic arbitration, as was demonstrated above, the problem of multiplicity of claimants only recently appeared in investment arbitration.

Chapter 2 summarizes the jurisdictional requirements and the issue of admissibility of claims under the ICSID Convention. This indispensable analysis is followed by a brief summary of the majority decisions and dissenting opinions in Abaclat $^{60}$ and Ambiente Ufficio ${ }^{61}$. This part of the paper provides the necessary tools for in-depth analysis of the correctness of the reasoning and findings made in those two cases.

\section{General jurisdictional requirements under the ICSID Convention}

While this article does not seek to provide a comprehensive overview of the multiple nuances concerning jurisdictional requirements that arise under the ICSID Convention, the subject must be broached so as to better assess the compatibility of the ICSID Convention with mass claims proceedings. The

\footnotetext{
58 Alexander Blumrosen, 'The Globalization of American Class Actions: International Enforcement of Class Action Arbitral Awards' in Permanent Court of Arbitration (eds), Multiple party 355.

${ }^{59}$ Born (n 49) 1231-32; J. Brian Casey, 'Commentary: class action arbitration should be available’ (2006) 9 The Lawyers Weekly 25:44; Daniele Favalli, Joseph M Matthews (n 56) 25-26.

${ }^{60}$ Abaclat and others $\mathrm{v}$ Argentine Republic, ICSID Case No. ARB/07/5, Decision on Jurisdiction and Admissibility, August 2011< http://www.italaw.com/sites/default/files/case-documents/ita0236.pdf> accessed 13 November 2015.

${ }^{61}$ Ambiente Ufficio S.P.A. and others (Case formerly known as Giordano Alpi and Others) $\mathrm{v}$ Argentine Republic, ICSID Case No. ARB/08/9, Decision on Jurisdiction and Admissibility, $\quad 8 \quad$ February 2013 https://icsid.worldbank.org/ICSID/FrontServlet?requestType=CasesRH\&actionVal=showD oc\&docId=DC2992 En\&caseId=C340 accessed 13 November 2015.
} 
following analysis limits itself to issues that may cause problems in that context.

Jurisdiction of an ICSID tribunal is regulated by Art. 25 of the ICSID Convention. This provision regulates the requirements for jurisdiction of an ICSID tribunal, namely rationae personae, rationae materiae and rationae temporis. In addition, an arbitral tribunal has to ascertain that the parties have consented to have their dispute decided by an ICSID tribunal (rationae voluntatis). Those requirements constitute the outer limits of the jurisdiction of the Centre and lie outside the disposal of states and investors ${ }^{62}$. The following sections briefly describe all those elements with the exception of rationae temporis, which is irrelevant for the purposes of this article.

\section{Consent under the ICSID Convention}

"Consent of the parties is the cornerstone of the jurisdiction of the (ICSID) Centre" ${ }^{\text {"63 }}$. It is a sine qua non requirement for the jurisdiction of an ICSID tribunal ${ }^{64}$. The mere fact that a state ratified the ICSID Convention does not mean that either a state or a national of a particular state has given its consent to arbitration under the auspices of ICSID and that it may become a party to ICSID arbitration without taking any further steps ${ }^{65}$. An additional expression of consent is required from both the state and the investor.

state may consent in three different ways: in a bilateral or multilateral investment treaty ("BIT"), in national legislation or in a contract with an investor $^{66}$. The scope of a state's consent to arbitration is limited by the content of the relevant international treaty or national law, especially the provisions defining the investment and investor, which are, generally, rather broad ${ }^{67}$.

However, a unilateral act by a state in one of these forms does not amount to consent sensu stricto - this is only a standing, general offer of a state $^{68}$ and it needs to be complemented by the investor's acceptance ${ }^{69}$. The investor accepts this offer either in writing at any time before a claim is brought $^{70}$ or by the initiation of ICSID arbitration further to a request for

\footnotetext{
${ }^{62}$ Christoph Schreuer (eds), Loretta Malintoppi, August Reinisch, Anthony Sinclair, The ICSID Convention: A Commentary. Art. 25 (Cambridge University Press 2009) 7.

${ }^{63}$ International Bank for Reconstruction and Development, Report of the Executive Directors on the Convention on the Settlement of Investment Disputes between States and Nationals of Other States (18 March 1965), (1993) 1 ICSID Reports 23-33.

${ }^{64}$ Lucy Reed, Jan Paulson, Nigel Blackaby, Guide to ICSID Arbitration (Kluwer Law International 2010) 21.

${ }^{65}$ Rudolf Dolzer, Christoph Schreuer, Principles of International Investment Law (Oxford University Press 2012) 243.

${ }^{66}$ Andrea Steingruber, Consent in International Arbitration (Oxford University Press 2012) 186.

${ }^{67}$ R. Doak Bishop, 'Multiple Claimants in Investment Arbitration: Shareholders and Other Stakeholders' in Permanent Court of Arbitration (eds), Multiple party actions in international arbitration (Oxford University Press 2009) 239.

${ }^{68}$ Steingruber (n 66) 190.

${ }^{69}$ ibid 186, 200.

70 Under this label one may indicate conclusion of an investment agreement or communication to the host state that an offer was accepted, see Andrea Steingruber 201; Southern Pacific Properties (SPP) (Middle East) v Arab Republic of Egypt, ICSID Case No. ARB/84/3, Decision on Jurisdiction II, April 14, 1988.
} 
arbitration $^{71}$. Only then does a state's offer and the investor's acceptance jointly constitute executed consent.

This issue may create problems in the context of mass claims, since in the case of a significant number of claimants an arbitral tribunal may not be able to properly review all requests for arbitration. Therefore, both tribunals and claimants may, and probably will, come up with new methods for ascertaining the existence of requisite consent, ${ }^{72}$ which must in turn comply at all times with the ICSID Convention and ICSID Arbitration Rules.

In addition, under Art. 25 (4) of the ICSID Convention "any Contracting State may, at the time of ratification, acceptance or any time thereafter, notify the Centre of the class or classes of disputes which it would or would not consider submitting to the jurisdiction of the Centre". Contracting states are therefore free to indicate what type of disputes cannot be decided in investment arbitration under the ICSID system. They can limit the scope of their consent as they wish.

Under Art. 25 (1) of the ICSID Convention and Art. 36 (1) of the ICSID Convention (which deals with requests for arbitration) consent must be in writing ${ }^{73}$. It is the only formal requirement imposed by the ICSID Convention, ${ }^{74}$ but failure to comply results in dismissal of the case. A request for arbitration fulfils the obligation of consent in writing ${ }^{75}$.

Consent, once given by both parties, is irrevocable, ${ }^{76}$ but this "irrevocability" appears nowhere as an additional requirement for validity of the consent. Additionally, once consent is perfected, this irrevocability characteristic means that no new conditions/limitations on consent can be introduced by a state ${ }^{77}$.

When a state expresses its general offer in an international treaty, the law governing this "first" part of consent is international law, in particular the Vienna Convention on the Law of Treaties ("Vienna Convention") 7879 .

However, one must bear in mind that an international treaty does not suffice for perfected consent, and the second element, the investor's acceptance, will be governed by a different law, whether national or international $^{80}$. If consent to arbitration is given by a state and an investor in an investment agreement concluded directly between them, the applicable law is the law chosen by the parties; if this is the case, an arbitral tribunal shall conduct an analysis analogical to the one used in commercial arbitration in the

\footnotetext{
${ }^{71}$ Steingruber (n 66) 189.

${ }^{72}$ See section II.2.

${ }^{73}$ International Bank for Reconstruction and Development, Report of Executive Directors of the ICSID Convention, 18 March 1965, no. 23.

${ }^{74}$ Christoph Schreuer, ICSID Convention Commentary, Art. 25 (Cambridge University Press 2001) 379, 374.

${ }^{75}$ Chittharanjan Felix Amerasinghe, 'Submissions to the Jurisdiction of the ICSID (1974) 5 Journal of Maritime Law and Commerce 211, 217; Christoph Schreuer, ICSID Convention Commentary (n 74) 416.

76 Steingruber (n 66) 216-7.

${ }^{77}$ Schreuer, Malintoppi, Reinisch, Sinclair (n 62) 599.

78 Vienna Convention on the Law of Treaties, concluded in Vienna on 23 May 1969 $<$ https://treaties.un.org/doc/Publication/UNTS/Volume\%201155/volume-1155-I-18232English.pdf.> accessed 13 November 2015.

${ }^{79}$ Steingruber (n 66) 230.

${ }^{80}$ ibid 230 .
} 
case of law governing the substantive validity of an arbitration agreement ${ }^{81}$. However, when issues related to the ICSID Convention are at stake, international law applies ${ }^{82}$. In addition, since the relation between a foreign investor and a host state is contractual in nature, not only are the expressions of consent made by a state relevant, but the investor's understanding of it matters as well ${ }^{83}$.

What is more, there is a significant incoherence between scholars' and arbitral tribunals' takes on the correct method of interpreting a state's consent. Three major approaches exist: the first is restrictive, focusing on reaffirming the protection of sovereign rights that are in part given up by an offer to arbitrate ${ }^{84}$ the second is expansive, underlying the need for protection of the investor's rights; ${ }^{85}$ the third is balanced, and tries to avoid tilting in either of those directions ${ }^{86}$. The third shall be given preference ${ }^{87}$.

Although consent of the parties is indispensable, other objective criteria prescribed in Art. 25 of the ICSID Convention must be fulfilled. Their importance is summarized below.

\section{Jurisdiction rationae personae under the ICSID Convention}

Jurisdiction rationae personae is regulated by Art. 25 of the ICSID Convention, and for the purposes of this analysis it is worth citing it at length: "(1) The jurisdiction of the Centre shall extend to any legal dispute arising directly out of an investment, between a Contracting State (...) and a national of another Contracting State, which the parties to the dispute consent in writing to submit to the Centre.

(2) "National of another Contracting State" means:

(a) any natural person who had the nationality of a Contracting State other than the State party to the dispute on the date on which the parties consented to submit such dispute to conciliation or arbitration as well on the date on which the request was registered pursuant to paragraph (3) of Article 28 or paragraph (3) of Article 36, but does not include any person who on either date also had the nationality of the Contracting State party to dispute;"

For the purposes of this paper what matters is the nationality of a natural person ${ }^{88}$. To take advantage of the ICSID system, a foreign investor needs to demonstrate that he holds the nationality of one of the ICSID

\footnotetext{
${ }^{81}$ ibid 227.

82 ibid 227.

83 ibid 234; Occidental Exploration \& Production Company v Republic of Ecuador (2005) EWCA Civ 1116, [2006] QB 432.

${ }^{84}$ Société Ouest Africaine des Bétons Industriels v Senegal, ICSID Case No. ARB/82/1, Award, February 24, 1988, (1994) 2 ICSID Reports 185, 205.

${ }^{85}$ Tradex Hellas S.A. v Republic of Albania, ICSID Case No. ARB/94/2, Decision on Jurisdiction, December 24, 1996, (2002) 5 ICSID Reports 47.

${ }^{86}$ SPP v Egypt (n 70) 143-4; Renta 4 SVSA et al. v the Russian Federation, Arbitration Institute for the Stockholm Chamber of Commerce Award No. 24/2007, Award on Preliminary Objections, March 20, 2009 http://cisarbitration.com/wpcontent/uploads/2013/02/Renta-4-Yukos-Russian-Federation-Preliminary-Objections-

Award.pdf accessed 13 November 2015.

${ }^{87}$ Steingruber (n 66) 239.

${ }^{88}$ For an overview of this of this topic see Dolzer, Schreuer (n 65) 47.
} 
Convention contracting states. Additionally, when substantive protection is granted by an investment treaty, whether BIT or multilateral (for example NAFTA), ${ }^{89}$ an investor has to show that he holds the nationality of one of the contracting states ${ }^{90}$. He cannot bring a claim against a state whose nationality he himself holds.

International treaties may contain their own definition of investment, but this possibility was not used in most of them. However, if a definition is present, a tribunal at the stage of examining the jurisdiction of the Centre shall ascertain that an individual complies with those specific requirements.

Evidently, an arbitral tribunal will decline jurisdiction if an investor fails to fulfil the nationality requirement.

\section{Jurisdiction rationae materiae under the ICSID Convention}

Pursuant to Art. 25 (1) of the ICSID Convention, jurisdiction rationae materiae extends to a 'legal dispute arising out of investment.' The elements relevant for a discussion on this jurisdictional requirement are: a measure adopted by a state, existence of a legal dispute, relation between a state measure that allegedly violates an international standard of protection and the legal dispute, and finally, existence of a protected investment ${ }^{91}$. The abundance of scholarly work and case law, combined with the concise nature of this paper, precludes the author from engaging in a comprehensive analysis of all those areas.

What matters for the purpose of analysis of the issue of mass claims is the definition of investment, which remains one of the most controversial concepts in ICSID jurisprudence but is at the same time the most crucial for jurisdiction of an ICSID tribunal ${ }^{92}$. The main controversy is whether the term 'investment' has its own objective meaning, or whether it is left to, for example, states that conclude a BIT to specify what they deem an investment. Bearing in mind that the issue has yet to be resolved, the problem remains of what conditions must be fulfilled to conclude that a particular operation is indeed an investment. The most important question, though, is whether sovereign bonds lie within the scope of the definition of investment ${ }^{93}$.

\section{Admissibility of claims under the ICSID Convention}

Jurisdiction and admissibility of claims are separate issues that are not to be conflated. Jurisdictional questions concern an arbitral tribunal and its competency to deal with a case ${ }^{94}$. Admissibility is more related to the claim itself $^{95}$.

\footnotetext{
89 North American Free Trade Agreement, Chapter Twenty < https://www.nafta-secalena.org/Default.aspx?tabid=97\&ctl=SectionView\&mid=1588\&sid=ed3bd8c9-2d73-45fb9241-d66364f8037a\&language $=$ en-US $>$ accessed 13 November 2015.

${ }^{90}$ Dolzer, Schreuer (n 65) 46.

${ }^{91}$ Steingruber (n 66) 256.

92 Dolzer, Schreuer (n 65) 233.

${ }^{93}$ For the possible answers see Michael Waibel, 'Opening Pandora's Box: Sovereign Bonds in International Arbitration' (2007) 101 American Journal of International Law 711-759.

${ }^{94}$ Jan Paulsson, 'Jurisdiction and admissibility' in Gerald Aksen and others (eds), Global Reflections on International Law, Commerce and Dispute Resolution: Liber Amicorum Robert Briner (ICC Publishing 2005) 617.

95 ibid.
} 
The basic difference between those two concepts is readily visible when one realizes that a tribunal may have, in abstract terms, jurisdiction to decide a particular case, but cannot exercise its jurisdiction because of additional obstacles related more to the claim as brought.

Another key difference between jurisdiction and admissibility occurs when it comes to the legal consequences of a decision on jurisdiction and admissibility. In the former case a national court or an ICSID ad hoc tribunal under Art. 52 of the ICSID Convention is competent to revise a decision of an arbitral tribunal. In the latter, a national court has no power to re-examine the case $^{96}$.

Issues that could be indicated as examples of admissibility problems are: contractual choice of forum, denial of benefits clauses and "dispositions relating to legal and beneficial ownership of the investment."

From the analysis undertaken in the preceding sections it is clear that the nationality of the investor and the consent of both state and investor can by no means be termed an admissibility problem - the two are clear-cut jurisdictional obstacles related to the empowerment of an arbitral tribunal to decide a case.

\section{ICSID tribunal case law related to "mass claims"}

Proceedings in which two or more claimants file a joint request for arbitration at a time are not a recent innovation in ICSID. In the past, the ICSID Secretary General has registered numerous requests of this type, ${ }^{98}$ notwithstanding the fact that neither the ICSID Convention nor ICSID Arbitration Rules provide for an explicit procedure for dealing with multiparty proceedings. Among those cases, Bernardus Henricus Funnekotter is worth mentioning. In this case, 14 farmers from the Netherlands initiated a case under the Netherlands - Zimbabwe BIT. The arbitral tribunal rendered an unprecedented decision allowing different BITs and procedural rules to be used in one case ${ }^{99}$.

Though this finding was undoubtedly novel, it was by no means controversial since travaux préparatoires of the ICSID Convention confirm that the drafters of the Convention had envisaged such a possibility ${ }^{100}$. Conversely, such a possibility is not so obvious in the case of bringing mass claims before an ICSID tribunal. The discussions below concern recent developments in this field, with special attention paid to the widely commented ruling of the ICSID arbitral tribunal (consisting of Jan van den Berg, Pierre Tercier and Georges Abi-Saab) rendered in Abaclat.

\footnotetext{
${ }^{96}$ Except for violation of public policy and manifest excess of power by an arbitral tribunal.

${ }^{97}$ Zachary Douglas, The International Law on Investment Claims (Cambridge University Press 2009) 148.

98 Antoine Goetz and others v Republic of Burundi, ICSID Case No. ARB/95/3, Award, September 2, 1998, (2004) 6 ICSID Reports 5; Champion Trading Company and Ameritrade International, Inc. v Arab Republic of Egypt (ICSID Case No. ARB/02/9), Decision on Jurisdiction, October 21, 2003, (2004)19 ICSID Rev.-FILJ 275.

${ }^{99}$ Bernardus Henricus Funnekotter and others v Republic of Zimbabwe, ICSID Case No. ARB/05/6, Award, April 22, 2009, <https://icsid.worldbank.org/ICSID/FrontServlet> accessed 13 November 2015.

${ }^{100}$ Lamm, Pham, Meise Bay (n 51) 60.
} 


\subsection{Abaclat $v$ Argentina \\ a) Majority decision}

The complicated fact pattern and multidimensional nature of Abaclat, involving a multiplicity of claimants who held Argentinian bonds, led the tribunal to decide on numerous controversial issues related to the jurisdiction of the tribunal, admissibility of claims and qualification of sovereign bonds as an investment. This paper concerns jurisdictional and procedural aspects; therefore it is confined to those findings of the tribunal that are related to the issue of mass claims.

Disputes with a multiplicity of claimants are not a new creature in the realm of ICSID arbitration ${ }^{101}$. However, it was not until the cases related to the Argentina crisis when, for the first time, a respondent state objected to the tribunal's jurisdiction or admissibility precisely because of the multiplicity of entities on the claimant side.

The decision of the tribunal on Jurisdiction and Admissibility rendered on 4 August 2011 concerned the pre-merits aspects of a case brought in relation to Argentina's default and subsequent debt restructuring. This history began when Argentina issued Law 24,156, which served as a basis for issuing bonds aimed at raising capital for economic growth. 83 of the 179 bonds were allegedly purchased by Abaclat Claimants ${ }^{102}$. As a result of the 2001 crisis and subsequent sovereign default, Argentina deferred external bond debt owed to both domestic and external creditor ${ }^{103}$. Eight major Italian banks created the Task Force Argentina (hereinafter "TFA") with a view to conducting, on behalf of Italian bondholders, negotiations concerning settlement of disputes with Argentina ${ }^{104}$. The negotiations pursued by TFA failed, and in 2005 Argentina offered the bondholders a one-time bond exchange option, ${ }^{105}$ but numerous bondholders refused to participate in the restructuring. TFA obtained authorization from 180,000 Italian bondholders to initiate a mass claim before an ICSID tribunal. This number fell to 60,000 after Argentina's second exchange offer of $2010^{106}$. The proceeding was bifurcated into two phases: jurisdictional and substantive ${ }^{107}$.

In its procedural decision, the tribunal analysed three main issues related to mass claims: first - consent of the parties to class action, second - lack of regulation concerning mass claims in the ICSID Convention, the ICSID Arbitration Rules and the Argentina-Italy BIT and the meaning of this silence, third - assurance of Argentina's rights to present a full defence if mass claims were to be heard.

The first issue is the existence of consent of the parties to arbitration. In the present case Argentina offered to have future investment disputes resolved in ICSID Arbitration in the Agreement between the Republic of Italy and the Argentine Republic on the Promotion and Protection of Investments

\footnotetext{
101 Ambiente Ufficio Majority decision (n 61) 126-127, 135-7, 141; Ambiente Ufficio Dissenting opinion (n 61) 79,82, 95-7.

102 Abaclat Majority decision (n 60) 50.

103 ibid 52,56,58.

104 ibid 65

105 UNCTAD, Sovereign Debt Restructuring and International Investment Agreements, (2011) IIA Issues No. 2, (July) < http://www.unctad.org/en/docs/webdiaepcb2011d3 en.pdf $>$ accessed 13 November 2015.

${ }^{106}$ Abaclat Majority decision (n 60) 216.

107 ibid 127.
} 
of 1993 (hereinafter "Argentina-Italy BIT"). This offer, as indicated in point 2.2. above, in order to be "executed consent" shall be perfected by a claimant's acceptance in the form of a request for arbitration. But in this case the mechanism used by multiple claimants, the so-called TFA mandate package, was significantly different. The TFA Mandate package was composed of several documents, ${ }^{108}$ and it served as a tool for multiple claimants to express consent to ICSID arbitration. Therefore, not every claimant filed a separate request for arbitration, which constitutes consent to arbitration.

As the tribunal specified, the vital question to be answered was whether "in view of the content and specifications of the TFA Mandate Package, the alleged circumstances surrounding its signature and the representation mechanisms implemented by such package, can Claimants' consent to ICSID arbitration still be considered a free and informed consent? " 109 However, the tribunal held that the power of attorney attached to the TFA Mandate package was sufficiently clear and unambiguous as to constitute a written document of consent ${ }^{110}$.

The TFA mandate package solution used in this case posed a question of equality of arms between the respondent and claimants. It was emphasized that some rights that the claimants agreed to cede to the Italian banks through the TFA Mandate package were balanced by the advantages obtained, the most important one being that the cost of the proceedings was to be incurred by the banks, ${ }^{111}$ not the bondholders, who presumably would not have had enough money to initiate and continue the proceedings separately. By the bondholders signing those documents, TFA became a third-party funder of this investment arbitration. The tribunal decided that the claimants were aware of the consequences related to acceptance of the TFA Mandate Package, and additionally that they benefited from it. To avoid problems related to ascertaining jurisdiction over 60,000 claimants, the tribunal decided that restrictions imposed upon claimants' rights in the proceedings (since they had waived some of their procedural rights) were an issue of admissibility and that claimants were perfectly aware of what they were doing ${ }^{112}$. As a result, no fraud, coercion or mistake occurred that could possibly invalidate this consent $^{113}$. In the tribunal's view, all the above mentioned circumstances may possibly cause inadmissibility of claims, but not lack of jurisdiction of the tribunal.

The tribunal held that Argentina's allegations of falsification of a signature on power of attorneys were of no importance at this stage of proceedings "and will - if necessary - be examined when dealing with issues relating to individual Claimants". The tribunal made an assumption that each power of attorney submitted was signed by the relevant claimant ${ }^{114}$.

\footnotetext{
${ }^{108}$ See detailed list in ibid $450-1$.

109 ibid 449.

110 ibid 453 .

111 ibid 458 .

112 ibid 179.

113 ibid 466.

114 ibid 454.
} 
It was also decided that the consent of the claimants was informed, ${ }^{115}$ namely that they were aware of the risks and consequences related to ICSID arbitration. The tribunal held that in the present decision it would not finally conclude whether each claimant validly consented to the present arbitration. The reason for this finding was the representation mechanism implemented by the TFA Mandate Package ${ }^{116}$.

The tribunal also examined the validity of Argentina's consent. Argentina expressed its consent to ICSID jurisdiction in Art. 8(3) of the ItalyArgentina BIT. One problematic issue was whether Argentina also implicitly consented to "mass claims" arising out of sovereign debt restructuring. The key question was whether a mass claim proceeding is an issue that requires express consent in the applicable BIT (or the ICSID Convention/ICSID Arbitration Rules), or whether a mass proceeding is simply a modality of conduct of a proceeding, rendering general consent sufficient. If the latter option is correct, express reference to mass claims would not be necessary and in every case a state will be deemed to have agreed, implicitly, to have mass claims be covered by such consent. However, it should be noted that mass claims are unknown to both Italian and Argentinian law ${ }^{117}$.

The tribunal found that mass action does not require special consent of a respondent. It held that the question to be asked is "can ICSID arbitration be conducted in the form of mass proceedings, considering that this would require an adaptation and/or modification by the tribunal of certain procedural rules provided for under the current ICSID framework?"118 For the tribunal the relevant question is not whether a state needs to expressly consent to mass claims proceedings, but whether mass claims are permissible within the boundaries provided by the ICSID Convention and under the ICSID Arbitration Rules, which, for this tribunal, was a question of admissibility ${ }^{119}$.

The second main question for the tribunal was the meaning of the silence of the ICSID Convention and ICSID Arbitration Rules about mass claims. Therefore, the issue for the tribunal to decide was whether this is a lacuna or qualified silence, the latter meaning that mass claims cannot be brought before an ICSID tribunal ${ }^{120}$. In order to conduct this analysis the tribunal extensively used the Argentina - Italy BIT, whose Art. 1 refers to instruments of a collective nature. The majority held that "it would be contrary to the spirit of ICSID to interpret the silence as qualified silence and thus the treaty's silence on mass claims is a gap, giving the Tribunal the power to step in." 121

The tribunal held that Art. 44 of the ICSID Convention and Art. 19 of the ICSID Arbitration Rules empower it to introduce into proceedings any such modification as is needed to make it possible to hear mass claims, since

\footnotetext{
115 ibid 461.

116 ibid 424.

117 Sebastian Perry, 'Green light for Mass Claims against Argentina' Global Arbitration Review $\quad<$ http://globalarbitrationreview.com/news/article/29768/green-light-mass-claimagainst-argentina $>$ accessed 13 November 2015 .

118 ibid 491.

119 ibid 492.

120 ibid 517.

121 ibid 518-9; Jessica Beess und Chrostin, 'Sovereign Debt Restructuring and Mass Claims Arbitration before the ICSID, The Abaclat Case' (2012) 53 (2) Harvard International Law Review 514.
} 
those modifications will not relate to the substance or object of a claim, but to the method of examination and presentation of a claim ${ }^{122}$.

As to the third issue, pursuant to the tribunal's decision it is possible to limit the respondent's procedural rights (since not every individual claimant would have an opportunity to present its arguments); ${ }^{123}$ however, this limitation, as the tribunal held, would not negatively affect Argentina's procedural position due to the homogeneity of the claimants' claims ${ }^{124}$. The tribunal stressed that what matters here is whether the mass claims brought arose out of the same fact pattern related to the same measures adopted by the state and whether the same type of breach is based upon the same treaty. The tribunal concluded that all those cumulative requirements were fulfilled in the case at hand and therefore the claims are sufficiently homogenous ${ }^{125}$. The majority also decided that modifications to the arbitral procedure had only a limited effect on Argentina's defence rights and it was not certain whether the defence rights that were taken from Argentina were to any extent necessary to protect Argentina's procedural rights ${ }^{126}$.

The tribunal put emphasis on the alternative before Argentina, which was to face 60,000 individual claims, which would undoubtedly be harder to deal with simultaneously. The tribunal concluded by stating that a mass proceeding is only a modality of ICSID arbitration, thus the tribunal had the power to use a procedure that was significantly different from the usual ICSID procedures $^{127}$.

As a result of the above considerations, the tribunal found that it had jurisdiction to hear the case on its merits.

\section{b) Dissenting opinion of Georges Abi-Saab}

The majority point of view was not shared by Georges Abi-Saab ${ }^{128}$. In his dissenting opinion ("Abi-Saab dissenting opinion") he addressed de novo the issues that were analysed by the majority. He indicated that the tribunal lacked jurisdiction to hear the present collective mass claims action because Argentina had at no time consented to it. An arbitral tribunal does not have the power to invent new procedures to deal with such an action. According to Abi-Saab, the majority's characterization of the case as one that started as aggregate but then transformed into collective proceedings, is incorrect. He found that such "genetic engineering does not work" and that the claimants" claims remained individualized ${ }^{129}$. Therefore it is not possible to treat the claims, judicially, as one claim ${ }^{130}$.

\footnotetext{
${ }^{122}$ Abaclat Majority decision (n 60) 534-5.

123 ibid 536.

124 ibid 545.

125 ibid 544 .

126 ibid 545.

127 ibid 534-5, Jessica Beess und Chrostin (n 121) 514.

128 Abaclat and Others v Argentine Republic, Decision on Jurisdiction and Admissibility,

Dissenting Opinion of Professor Georges Abi-Saab, November 28, 2011

$<$ http://italaw.com/sites/default/files/case-documents/ita0237.pdf $>$ accessed $\quad$ on 13

November 2015, 2.

${ }^{129}$ ibid 139.

130 ibid 140 .
} 
Abi-Saad criticized the majority's characterization of Argentina's preliminary objection with regard to its consent as an issue of admissbility, not of jurisdiction. He opined that Argentina's consent cannot be interpreted to cover the power of the tribunal to hear collective mass claims actions requiring resort to atypical or abnormal procedures and that secondary consent is needed ${ }^{131}$. As a result, the tribunal does not have jurisdiction to hear the case $^{132}$. Abi-Saab also disagreed with the alleged power of a to adapt the ICSID arbitration rules in such a way as to enable it to handle mass claims ${ }^{133}$.

\subsection{Ambiente Ufficio S.p.A and others v Argentina}

Ambiente Ufficio was the second case that arose out of the Argentinian crisis. This case concerned the same factual background (financial crisis and debt restructuring) as Abaclat $^{134}$.

\section{a) Majority decision}

As in Abaclat the tribunal in Ambiente Ufficio indicated that it would not determine whether it had jurisdiction over every single claimant, and postponed this determination to the substantive phase. The tribunal refrained from setting forth and reviewing compliance with the general jurisdictional requirements and admissibility of the claims, and chose to conduct a casespecific analysis ${ }^{135}$. The tribunal underlined the similarity between the fact patterns in the case at stake and Abaclat. While pointing out the lack of any doctrine of stare decis in investment arbitration, it stated that it would not abstain from using the reasoning adopted by the Abaclat tribunal where applicable $^{136}$.

The tribunal held that the case was not a "class action" or "mass claims" type ${ }^{137}$. First, the tribunal differentiated the current proceeding from the US-type class action and underlined that the representative element present in Abaclat was lacking in Ambiente Ufficio ${ }^{138}$. The tribunal emphasized that the claimants were clearly identified, they acted on their own behalf and any decision rendered by the tribunal would be binding solely upon the identified claimants $^{139}$.

Second, the majority decided that in the present case the application of a special procedural arrangement was not justified because of the number of claimants being considerably lower than in Abaclat $^{140}$. The tribunal stressed that this proceeding could not be referred to as mass claims precisely because of discrepancies in legal doctrine related to this term ${ }^{141}$.

The majority also warned against using the terms "aggregate proceedings" and "collective action" if these terms would serve as a "backdoor" to introduce elements of class action or mass claims into ICSID

131 ibid 177, 190.

132 ibid 191.

133 ibid 194.

134 ibid 56-62.

135 ibid 6.

136 ibid 10-13.

137 ibid 114.

138 ibid 115-6.

139 ibid 116.

140 ibid 120.

141 ibid. 
$\operatorname{arbitration}^{142}$. The majority qualified the case as a multi-party proceeding. This conclusion influenced the subsequent discussion, in which the tribunal coherently referred to multi-party proceedings, not to mass claims or even aggregate proceedings. For example, the tribunal pointed out that multi-party proceedings were a subject of the ICSID Convention's travaux préparatoires, and it did not address the issue that "mass claims" were not discussed. Similarly, the tribunal addressed the Respondent's argument about the nonexistence of collective proceedings at the time of drafting the ICSID Convention. The tribunal opined that Argentina referred to mass claims, not to multi-party proceedings, ${ }^{143}$ and therefore this argument could not have been sustained.

Interestingly, the crucial issue for the arbitrators seems to have been the difference in the number of claimants in Abaclat and in the case at hand. It was underlined that the conclusion of the tribunal in Abaclat was the first time when mass claims was brought before ICSID was caused by the fact that there were 60,000 claimants in that case. For the tribunal in Ambiente Ufficio this number was the main reason why in Abaclat this qualification was applied. Since in the case at hand the number of claimants was significantly lower, namely only a few dozen Claimants, it could not have been qualified as a mass proceeding ${ }^{144}$. The tribunal mentioned that, for instance, in Goetz and others $v$ Burundi the fact that the proceeding was initiated by 6 Belgian shareholders was not a bar to the jurisdiction of a tribunal ${ }^{145}$.

Concerns over due process and manageability of the proceeding did not constitute, according to the tribunal, any obstacle to jurisdiction, mainly because of the multi-party (as opposed to class) nature of the proceeding in the case at hand ${ }^{146}$.

The tribunal addressed the issue of consent of the claimants. It decided that, contrary to the Respondent's submissions, a representative's signature suffices to sign a request for arbitration and that the Claimants themselves need not sign ${ }^{147}$. The tribunal opined that the requirement of written consent must be examined within the framework of the ICSID Convention and pursuant to international law, if the latter is applicable, not under any domestic law ${ }^{148}$. The majority concluded that in the present case the request for arbitration, together with the relevant power of attorney of the Claimants' representatives, fulfils the requirements imposed by the ICSID Convention ${ }^{149}$.

As to the role of NASAM, ${ }^{150}$ the Claimants pointed out that it is not a financial institution or a bank, but it simply decided to "coordinate, organize and fund a legal action of holders of Argentine bonds"151. Unlike in Abaclat, it had no relations with Italian banks. The Respondent contended that the real party to this proceeding should be NASAM, not the Claimants, since under

142 ibid 121.

143 ibid 134.

144 ibid 135.

145 ibid 136.

146 ibid 164-6.

147 ibid 220.

148 ibid 236, 240-1.

149 ibid 244.

${ }^{150}$ North Atlantic Société d'Administration, a company from Monaco.

${ }^{151}$ Ambiente Ufficio Majority decision (n 61) 274. 
Art. 5 and 6 of the NASAM Mandate it is NASAM which has rights to recover the proceeds from the arbitration proceeding ${ }^{152}$ and, in addition, NASAM does not have Italian nationality.

The tribunal held that NASAM did not control the proceeding ${ }^{153}$ and stressed that the claimants' representatives did not take instructions from $\mathrm{NASAM}^{154}$. In the view of the tribunal "the NASAM Mandate does not interfere with the ability of the Claimants to conduct the present proceedings in their best interest and to instruct their counsel accordingly. In sum, in the Tribunal's opinion, there are no substantiated indications that there would be an external control of the present proceedings by an external actor or a conflict of interests which would undermine the proper exercise of jurisdiction by the Tribunal" 155 .

For their part, the Claimants asserted that they were Italian nationals, as required, and that all necessary copies of passports and certificates were submitted $^{156}$. In order to address the issue of nationality in this case one needs to consider Art. 25 of the ICSID Convention, Art. 1(2) of the Argentina-Italy BIT $^{157}$ and Art. 1 of the Additional Protocol to the Argentina-Italy BIT ${ }^{158}$. The tribunal decided that the burden of proving the negative elements resulting in the lack of jurisdiction rationae personae lies upon the Respondent ${ }^{159}$. The tribunal once again underlined that at this stage of the proceeding it would not examine compliance with the nationality requirement by every Claimant ${ }^{160}$. The majority held that in principle the documents provided by the Claimants were sufficient to meet the nationality requirement ${ }^{161}$. The tribunal reserved its right to re-visit that discussion at a later stage of the proceedings, if the Respondent submitted relevant documentation contesting the Claimants' nationality ${ }^{162}$.

To sum up the majority decision, the main feature which differentiates this case from Abaclat is its characterization by the tribunal - unlike in the latter, the tribunal classified it as "multiparty" rather than mass arbitration ${ }^{163}$. The main reason behind this conclusion was that the number of Claimants in Ambiente Ufficio was significantly lower than in Abaclat - 90 as opposed to $60,000^{164}$. But the reasons presented by the tribunal to substantiate this differentiation were not convincing enough.

\footnotetext{
152 ibid 286.

153 ibid 277.

154 ibid.

155 ibid 278.

156 ibid 288. where the investment was made".

${ }_{159}$ Ambiente Ufficio Majority decision (n 61) 312.

160 ibid 319.

161 ibid.

162 ibid 325.

163 ibid 122 .

164 ibid $119-120$.
}

157 Art. 1(2) "The term 'investor' means any physical or juridical person of one of the Contracting Party that has made, is making, or has assumed an obligation to make investment in the territory of the other Contracting Party. - 'physical person' means, for each Contracting Party, any physical person who has citizenship in that State, in accordance with its laws."

158 "With reference to Article 1 [of the BIT]; a. Physical persons of each Contracting Party may not benefit from this Agreement if, at the time of making the investment, they have maintained their domicile for more than two years in the territory of the Contracting Party 


\section{b) Dissenting opinion of Santiago Torres Bernandez}

One of the arbitrators, Sanatiago Torres Bernandez, issued a dissenting opinion ("Bernandez dissenting opinion"). He underlined that the task of an arbitral tribunal is to interpret the state's consent to arbitration as stated in the relevant BIT, and in the light of general policy considerations of investor protection. What matters is the intention of state parties to a BIT ${ }^{165}$. Bernandez criticized the majority's extensive reliance upon Abaclat and pointed to the lack of legal basis for doing so ${ }^{166}$.

Bernandez was of the opinion that silence on class action in the ICSID Convention and in the Argentina-Italy BIT does not mean consent to this type of proceeding, because ICSID tribunals are not given legislative jurisdiction or power ${ }^{167}$. For Bernandez, the proceeding in question was an example of "joinder of actions under the form of an aggregate proceeding"" 168 and since this variation is not regulated in the ICSID system it requires either consent or acquiescence of a respondent state ${ }^{169}$. This conclusion is supported by usage of a singular form ("a national of another Contracting State") in Art. 25 of the ICSID Convention. Using the ordinary meaning, as required by Art. 31 (1) of the Vienna Convention, this provisions allows one claimant, not many claimants, to bring a case before an ICSID tribuna $1^{170}$. For Bernandez, silence on that matter equals lack of consent, not the contrary, as was proposed by the majority ${ }^{171}$.

Bernandez also dealt with the cases mentioned by the majority as support for the finding that a multi-party proceeding is accepted within the framework of ICSID. His conclusion was that the majority had failed to demonstrate such a common practice ${ }^{172}$.

The dissenting arbitrator pointed out that secondary consent is possible and necessary in the case of multi-party arbitration, but not when it comes to class action, the latter being incompatible with the basic framework of the ICSID Convention $^{173}$. The arbitrator also criticized the majority finding of the existence of jurisdiction rationae personae in the absence of in concreto examination of whether the jurisdictional requirements were fulfilled by every claimant $^{174}$. For Bernandez it constituted a de facto prejudgement on compliance with the nationality requirement ${ }^{175}$. In addition, Bernandez disagreed with the allocation of the burden of proof between the parties that was adopted by the majority ${ }^{176}$.

\footnotetext{
165 Bernandez dissenting opinion 3-9.

166 ibid 38-41.

167 ibid 61.

168 ibid 73, however for Bernandez "aggregate proceeding" meant more "multi-party action", in the meaning adopted by the majority in Ambiente Ufficio, not in the meaning proposed by Abaclat tribunal.

169 ibid.

170 ibid 85-6.

171 ibid 75-80.

172 ibid 97.

173 ibid 104.

174 ibid 117-119.

175 ibid 134-6, 139.

176 ibid 139-145.
} 


\subsection{Giovanni Alemanni and others $v$ Argentina ${ }^{177}$}

On November 17, 2014, the tribunal in Giovanni Alemanni and others $v$ Argentina issued a decision on jurisdiction and admissibility. With regard to the fact pattern, this case is very similar to those two presented above; however it involved "only" 74 claimants.

Legal argumentation adopted by the parties in this case was considerably similar to the arguments used in Abaclat and Ambiente Ufficio. The tribunal in Alemanni pointed out that it was "not impressed by either of the two opposing arguments: either that a multi-party arbitration can only be brought where there has been a second, special consent to that effect; or (conversely) that the parties' (or the respondent's) specific consent is of no special relevance, in the particular context of a multi-party arbitration, to the establishment of the tribunal's jurisdiction." 178 For the tribunal "[i]n a BIT case ... where the consent of the respondent State is in issue, the question for consideration remains simply: on the proper interpretation of the BIT, has the respondent, or has it not, given a consent which is wide enough in scope to cover the proceedings brought (as in this case) by the multiple group of coclaimants." 179

Rejecting the findings of Abaclat and Ambiente Ufficio the tribunal indicated that the real issue is whether "the words "dispute arising directly out of an investment, between a Contracting State ... and a national of another Contracting State' as they appear in Article 25(1) of the ICSID Convention [are] to be understood as meaning 'dispute between a Contracting State and one, but only one national or another Contracting State." "180 The tribunal decided that there is no indication either in the ICSID Convention or in the ICSID Rules that supports a conclusion that "but only one" was meant to be included in the Article 25(1) of the ICSID Convention ${ }^{181}$. This constitutes a clear departure from the earlier findings of the tribunals, and it seems to be a more coherent and sophisticated attempt to introduce mass claims into ICSID $\operatorname{arbitration}^{182}$.

\section{Conclusions}

In summary, it is evident that the requirement of consent is crucial for the jurisdiction of an ICSID tribunal. The absence thereof constitutes an insurmountable obstacle for the possibility of an ICSID arbitral tribunal rendering a decision on merits. Clearly, rationae voluntatis must be

\footnotetext{
177 Giovanni Alemanni and others v Argentine Republic, ICSID Case No. ARB/07/8, Decision on Jurisdiction and Admissibility, November 17, 2014 $<$ http://www.italaw.com/sites/default/files/case-documents/italaw4061.pdf $>$ accessed 13

${ }^{182}$ For more information on this case see Stacy Strong, 'Consent in Multiparty Investment Arbitration - $\quad-\quad$ The Most Recent Installment' $<$ http://kluwerarbitrationblog.com/blog/2014/12/11/consent-in-multipartyinvestment-arbitration-the-most-recentinstallment/?utm source $=$ feedburner\&utm medium $=$ email\&utm campaign $=$ Feed $\% 3 \mathrm{~A}+\mathrm{Kl}$ uwerArbitrationBlogFull+\%28Kluwer+Arbitration+Blog +-+ Latest + Entries $\% 29>$ accessed 13 November 2015.
} 
differentiated from admissibility of claims. In particular, admissibility cannot serve as a tool for circumventing the obligation of compliance with jurisdictional requirements.

\section{MASS CLAIMS IN THE ICSID SYSTEM - WELCOME MODIFICATION OR PROCEDURAL MONSTER?}

\section{Introduction}

As was shown above, the majority that rendered the decision in Abaclat obviously had efficiency and compensatory concerns in $\operatorname{mind}^{183}$. Obviously, those issues are important, but to what extent can they overrule the tribunal's obligations of examining its jurisdiction in a given case? And is it correct to state, as the tribunal in Abaclat did, that "collective proceedings are (...) consistent with the purpose and object of the BIT, since the high number of claimants is inherent to the nature of the investments protected by the $B I T{ }^{\prime}{ }^{184}$ Or maybe Abi-Saab was right when he described mass claims proceedings under the ICSID Convention as "genetic engineering" that cannot work? This chapter addresses those questions and highlights some faults in the reasoning of the arbitral tribunals in Abaclat and in Ambiente Ufficio.

\section{Terminology used-admissibility of multiple-party proceedings?}

From the above considerations it is clear that in both Abaclat and Ambiente Ufficio the tribunals were trying to use various terminological tools to frame the real questions in a way that better fitted the conclusion of having jurisdiction in the cases. However, those methods were inappropriate for various reasons.

First, it shall be noted that the majority in Abaclat initially wrongly classified the proceeding as a class claims proceeding. In fact, neither any claimant nor the TFA acted as the Claimants' representative. The Claimants' claims were pleaded individually and the tribunal should have dealt with them in such a manner ${ }^{185}$. The tribunal also wrongly decided that the proceeding had transformed into an aggregate proceeding. However, it is hard to point to a particular moment when this change took place. And even if that transformation did take place, the tribunal failed to draw the proper conclusions from it: that adoption of a "transformation tool" had one purpose, which was to avoid the accusation of trying to introduce mass claims into the ICSID framework.

Second, aggregate proceedings in the form known in some jurisdictions means rendering a decision in relation to every member of a group. This, in turn, is not compatible with the reiterated statement in Abaclat and Ambiente Ufficio concerning the lack of a necessity to examine the

\footnotetext{
${ }^{183}$ Stacy I. Strong, 'Mass Procedure in Abaclat: Are They Consistent with the International Investment Regime?' 3 Yearbook on International Arbitration 21 $<$ http://papers.ssrn.com/sol3/papers.cfm?abstract $\mathrm{id}=2083219>$ accessed 13 November 2015.

$\overline{184}$ Abaclat Majority decision (n 60) 513.

${ }^{185}$ Hand van Houte, Bridie Mc Asey, 'Case Comment. Abaclat and Others v Argentine Republic, ICSID, the BIT and Mass Claims’ (2012) 27 ICSID Review 235.
} 
compliance of every claimant with jurisdictional requirements. Also, the justification of the Abaclat findings in this regard that was proposed in Ambiente Ufficio cannot be accepted. The number of claimants in mass claims or aggregate proceedings and in multi-party proceedings is not the only difference between those modes.

Finally, the tribunals' qualification of the issue of mass claims in ICSID as an admissibility problem is entirely inappropriate. From the brief overview in Chapter 2 it is clear that the issue of consent is not a question of admissibility, but of jurisdiction. The preliminary objection related to mass claims aims at the tribunal's power to decide; it does not attack a particular claim because of a particular feature of that claim. The following section deals precisely with this mistake.

\section{Jurisdiction of an ICSID tribunal to decide mass claims and consent of claimants and a respondent}

The present author opines that the tribunal skilfully escaped the real, jurisdictional problem of lack of rationae voluntatis and potential lack of rationae personae that occurred in this case. The tribunals' interpretations concerning secondary consent and compatibility of the ICSID Convention and ICSID Arbitration with mass claims were not correct.

Jurisdictional requirements are clear under Art. 25 of the ICSID Convention. Any ICSID tribunal is obliged to ascertain individually whether nationality and consent requirements were complied with in relation to every claimant. The mere fact that under TFA Instruction Letter and TFA Mandate each claimant declared ownership of Argentine bonds and its consent to ICSID arbitration ${ }^{186}$ is of no relevance to the tribunal's objective obligations to ascertain compliance with jurisdictional requirements.

In Ambiente Ufficio the tribunal avoided an examination of jurisdictional issues because of the Claimants' and respondent's advance consent that this issue would be individually reviewed in relation to every claimant at a later stage of the proceeding ${ }^{187}$. Even if the parties agreed to implement such a referral of jurisdictional problems during the merits phase, a tribunal cannot restrict its considerations to a "general assessment" of the existence of ratione personae and ratione voluntatis. Those issues need to be dealt with in the first phase of proceedings, before entering into the merits stage. One should notice that at the merits stage a tribunal will not re-enter into examination of fulfilment of jurisdictional requirements, therefore the "initial judgment" on this issue is in fact the final one, without admitting it.

The tribunal was indeed correct in concluding that the mere fact that there were several dozen claimants (assuming the tribunal classified this proceeding properly as multi-party, rather than class $)^{188}$ had no impact on its jurisdiction (provided the respondent consents to such effect, see point 3.4. below). At the same time a tribunal may lack jurisdiction because of obstacles related to a particular claimant. Referral to a merits phase ${ }^{189}$ obviously does not provide any efficiency justification. Why not answer this question at the proper stage of the proceeding rather than wait until the merits stage, wasting

\footnotetext{
${ }^{186}$ Abaclat Majority decision (n 60) 452.

${ }^{187}$ Ambiente Ufficio Majority decision (n 61) 167.

188 ibid.

189 ibid 168.
} 
the parties' time and money? Of course, since the parties agreed to the referral, this decision by the tribunal does not create problems of such gravity as other issues do.

Second, the author submits that every tribunal's task is to "discover, not to create meaning" 190 of relevant treaties. When either on a domestic or an international level a class action is allowed, this is explicitly provided by the relevant wording of the applicable legal provisions. And one must bear in mind the very special character of investment arbitration, when the sovereignty of states is at stake. It calls for a more than careful interpretation of the ICSID Convention and BITs. Class action is a very specific tool that requires the availability of additional procedural mechanisms to deal with it. One should clearly differentiate between a state's consent to arbitration and a state's consent to collective arbitral actions. Nothing in the wording of the ICSID Convention and ICSID Arbitration Rules supports the conclusion that investors may bring mass claims against a state.

Third, the concept of secondary consent appeared in ICSID jurisprudence in the context of consolidation ${ }^{191}$. The same solution should be applied to mass claims/ aggregate proceedings/ multiple-party proceedings. In fact, states that are not signatories to the ICSID Convention and whose consent does not appear in BIT/national law have not consented to mass claims proceedings. What they have consented to was ICSID arbitration as such, in its default mode of proceeding between one investor and a state.

Both silence and non-exclusion of the said types cannot be interpreted as consent to this very special type of proceedings. Of course, consent may also be given through a series of related documents, ${ }^{192}$ but it needs to be manifest and unequivocal. States at the time of drafting the ICSID Convention, and Argentina when signing the Argentina-Italy BIT, could not have envisaged that those treaties would cover mass claims/ multi-party arbitration. This excludes any conclusion that they have consented to those proceedings. The decisions in Abaclat and Ambiente Ufficio to the effect that no secondary consent is needed for mass claims or multiple proceedings are incorrect.

Stacy Strong was of a similar point of view when she stated that two types of consent need to be differentiated in arbitration. The first is to agree to arbitrate some types of disputes / a particular dispute. This is termed primary consent. The second type is consent to a particular type of procedure, and class action clearly falls under this heading. "This concept is by no means unique to class disputes, since traditional multiparty arbitrations are also required to establish secondary consent in cases where the arbitration agreement is silent

\footnotetext{
${ }^{190}$ Renta 4 S.V.S.A. (n 86) 93.

191 Pan American Energy, Procedural Details (n 105) $<$ http://icsid.worldbank.org/ICSID/FrontServlet?requestType=GenCaseDtlsRH\&actionVal $=$ ListPending $>$ accessed 13 November 2015.

${ }^{192}$ Antione Goetz and others v Republic of Burundi, ICSID Case No. ARB/01/2, Award, June 21 , 2012 , 1,139

$<$ https://icsid.worldbank.org/ICSID/FrontServlet?requestType=CasesRH\&actionVal=show Doc\&docId=DC2651_Fr\&caseId=C2> accessed 13 November 2015.
} 
or ambiguous as to multiparty treatment." 193 Therefore it is clear that the idea of secondary consent should not be surprising and the reluctance in Abaclat and Ambiente Ufficio to further develop this idea in the realm of investment arbitration is astonishing.

Also, the point of view of the Abaclat tribunal that the requirement of giving secondary consent would be contrary to the "spirit" of ICSID cannot be sustained. The fact that the financial instruments involved in a purported investment are "mass" in nature does not influence the separate issue of whether parties consented to mass proceedings. Leaving aside the fact that any qualification of bonds as an investment is at least controversial, compliance with the rationae materiae requirement shall not impact the separate issue of rationae voluntatis. The tribunal mixed them and drew clear-cut conclusions regarding the problem of consent itself from the problematic and not properly resolved issue of the existence of investments in the cases at hand.

In conclusion, there is a possibility of multi-party proceedings, and maybe even mass claims, before an ICSID tribunal, but not against a state's will. Secondary consent is a condition sine qua non of such proceedings. Therefore Szasz correctly pointed out that when all jurisdictional limitations are complied with and the parties have consented, nothing prevents an ICSID tribunal from carrying out multi-party proceedings ${ }^{194}$. But conversely, lack of this secondary consent is an obstacle that cannot be removed through the use of interpretative and rhetorical tools. In short, one might say that "all you need is consent".

For the sake of clarity and brevity, the whole subsequent argumentation is premised upon the existence of state consent to mass claims/ multi-party arbitration. The alternative scenario of a lack of state consent is not addressed since those questions simply would not arise in that situation.

\section{Suitability of the ICSID system for solving mass claims}

Neither the ICSID Convention nor the Argentina-Italy BIT provide for a detailed procedure applicable in such a case. Thus, in the absence of a specific procedure designed by the parties, the framework stipulated in the ICSID Convention is applicable. According to the majority in Abaclat the procedure it had invented/was about to invent to deal with the 60,000 claimants, was only a modification of the ICSID Convention and ICSID Arbitration Rules. The present author opines that this approach is incorrect in its entirety.

Above all, it is worth considering whether the tools (listed in chapter 2 above) adopted by international mass claims commissions and tribunals are suitable for proceedings before an ICSID tribunal. It may be argued that computerization and delegation of claims review to the ICSID secretariat is not prohibited, provided the decision is made by the arbitrators in accordance with Art. 42 of the ICSID Convention and Rule 16 of the ICSID Arbitration Rules. The sine qua non condition of such a delegation is direct supervision and control by an arbitral tribunal of every such procedural tool. The latter

\footnotetext{
193 Stacy I. Strong, 'Does Class Arbitration "Change the Nature" of Arbitration? Stolt Nielsen, AT\&T and Return to First Principles'(2012) 17 Harvard Negotiation Law Review 55-6.

${ }^{194}$ Paul C. Szasz, 'The Investment Disputes Convention - Opportunities and Pitfalls (How to Submit Disputes to ICSID)' (1970) 5 Journal of Law and Economic Development 26.
} 
technique entails initial review of the claims by the secretariat and delivering a report to the tribunal in which the secretariat shall identify issues common to all claims and suggest how those issues be handled. As long as the tribunal is at all times cognizant of all key evidentiary issues, it shall be permissible. However, the panel itself also needs to review a statistically representative sample of the claims, which requires expertise from either the tribunal or outside experts ${ }^{195}$.

Rendering a cover decision concerning many claimants, as opposed to an individual claimant, does not seem to run contrary to the ICSID Convention or the ICSID Arbitration Rules. The argument that it would be inconsistent with the requirement imposed by Art. 47 and Art. 48 of the ICSID Convention or Art. 47 (1) of the ICSID Arbitration Rules does not hold water ${ }^{196}$.

However, given the role and nature of the ICSID, neither ex officio discovery nor evidentiary presumptions and a relaxed standard of proof, applied by international tribunals and commissions mostly in disputes related to human rights and war, seem to be compatible with the ICSID Convention and ICSID Arbitration Rules ${ }^{197}$.

Statistics, because of the great reliance the Abaclat tribunal placed upon them, seem to be of particular importance for the purpose of this paper. This is a tool that may constitute an alternative to a relaxed standard of proof $^{198}$. It is used globally, "or on the level of the claims population as a whole". It is particularly useful when the number of cases is high and, as a result, time, costs and other resources needed to review claims individually would be prohibitive ${ }^{199}$. This method constitutes "the most radical departure from standard arbitral decision-making." 200 It cannot be overlooked that "such methods allow the resolution of claims without an effective review of all of the claims covered by the decision (which is the situation, for example, when decisions are taken on the basis of sampling), or to the extent that they allow approval of claims not supported by any or very little evidence, based on evidence available in other claims (regression analysis and statistical modelling). ${ }^{201}$ But those techniques may be used only if the jurisdiction of the arbitral tribunal is established. Limitation of sovereignty is of such importance that it cannot be presumed lightly, and statistical methods of examining the Claimants' consent and nationality, as in Abaclat, had precisely this effect. In addition, efficient as it is, the present author submits that this method is incompatible with the legal framework of the ICSID Convention. When a respondent state raises an objection, and when statistical tools are used to deal with such a fundamental issue as consent to arbitration, their incompatibility with the rule of due process is even more glaring. An arbitral tribunal is under an express obligation to assure itself that jurisdictional requirements are complied with by every single claimant. Failing to do so

\footnotetext{
${ }^{195}$ Heiskanen (n 8) 315.

196 ibid 316-7.

${ }^{197}$ Abaclat Majority decision (n 60) 317-9.

198 ibid 321.

199 ibid 321.

200 ibid.

201 ibid.
} 
could possibly be seen as grounds for annulment under Art. 52 of the ICSID Convention $^{202}$.

The finding of the Abaclat tribunal concerning its powers under Art. 44 of the ICSID Convention and Rule 19 of the ICSID Arbitration Rules requires closer analysis. By exercising power under Art. 44 of the ICSID Convention and under Rule 19 of the ICSID Arbitration Rules, a tribunal could not exceed the basic framework outlined by the ICSID Convention and the ICSID Arbitration Rules ${ }^{203}$. Typically, under those provisions tribunals make decisions concerning inter alia modalities of decision-making, organising oral proceedings on preliminary objections, delegation of power to a president to decide on issues like time-limits and production of documents ${ }^{204}$. One must bear in mind that any procedural decisions of an arbitral tribunal are at the bottom of the hierarchy of the various provisions and regulations of the ICSID system, ${ }^{205}$ subordinate to, among others, mandatory provisions of the Convention and procedures agreed by the parties. Usage of the class action modality significantly alters the default framework of the ICSID Convention, which was designed to apply to individual investor's claims. The basic defence rights of a respondent state are significantly limited during class action proceedings, and allowing the introduction of that limitation cannot be inferred either from Art. 44 of the ICSID Convention or from Rule 19 of the ICSID Arbitration Rules.

In addition, Art. 44 of the ICSID Convention is meant for filling procedural gaps, not for replacing existing rules when they are not suitable for a given case ${ }^{206}$. Such gaps should be minor and rather technical; this provision cannot be interpreted as empowerment for the creation of whole chapters of rules $^{207}$. What was "filing gaps" for the Abaclat tribunal in fact meant the adoption of completely new rules, requiring legislative power which an ICSID tribunal lacks. The so-called adaptations made in Abaclat significantly affected parties' procedural rights, and a tribunal does not have the power to do so since it also seriously affects parties' substantive rights. Leaving aside Argentina's defence rights, the tribunal's conclusion that the claimants knew what they were doing when they accepted the THA Mandate Package was also striking. The reason for this conclusion is the fact that Italian courts had found some signatures forged, a matter which was glossed over by the majority ${ }^{208}$. Someone whose signature was forged most definitely "did not know what he was doing".

What, then, would be an acceptable alternative from a legal point of view for dealing with mass claims? Perhaps state-to-state arbitration. For example, Art. 9 of Italy - Argentina BIT provides for such an opportunity. Another solution is of course legislative changes to the ICSID Convention and ICSID Arbitration Rules. By no means must the international community accept the introduction of mass claims proceedings into the ICSID system by the backdoor, through decisions of arbitral tribunals.

202 ibid 322.

${ }^{203}$ Schreuer (n 74) 688.

204 ibid 689.

205 ibid 690.

${ }^{206}$ Similarly in Abi-Saab Dissenting opinion (n 128) 201.

207 ibid 202.

208 ibid 231. 


\section{Homogeneity of claims}

The tribunal in Abaclat opined that the homogeneity of claimants' treaty claims is an argument in favour of the tribunal's jurisdiction. "The only relevant question is whether Claimants have homogenous rights of compensation for homogeneous damage caused to them by potential homogeneous breaches by Argentina of homogeneous obligations provided for in the BIT"209 and "specific circumstances surrounding individual purchases by Claimants of security entitlement are irrelevant." 210 The same reasoning was presented in Ambiente Ufficio ${ }^{211}$. This statement is flawed and cannot be endorsed. The best summary of mistakes and omissions of such findings are presented in Abi-Saab's dissenting opinion. It is true that if one tries hard enough, one always reaches a point where claims are sufficiently homogenous.

In addition, at the merits stage of proceedings, the issue of contractual differences between the claims finally emerges. What will a tribunal do then? Will it separate the claims for the purpose of awarding damages? That solution is an obvious non-starter.

\section{Due process considerations}

Adaptation of the ICSID Arbitration Rules to mass claims poses several questions concerning their coherence with due process principles. The respondent shall have an opportunity to be presented with every element of a claim and to respond to it in an adversarial process. Modifications implemented in Abaclat openly violated those rights under a cover of sufficiently homogenous claims. That would not be problematic if Abaclat were truly a mass claim proceeding, available to parties within the ICSID framework and consented to by the respondent. But since even Abaclat claimants maintained that their claims were not identical, there was no possibility of the existence of a mass claim. As a result, also for the sake of coherency of the tribunal, Argentina should have been given an opportunity to plead each of the 60,000 claims separately. Some mechanisms that compromise parties' procedural rights and exist in proceedings before international claim commissions, as referred to above, cannot be automatically transplanted into arbitral proceedings. Examples are dealt with below.

Of course, in many areas mass claims arbitration does not give rise to any concerns related to due process. Selection of an arbitrator does not seem to be as grave a problem as in the case of consolidation of proceedings. If claimants decide to bring a case as a mass, they shall be deemed to accept that they cannot exercise their otherwise existing right to appoint their own arbitrator.

It was argued that the mass claims proceeding was advantageous for Argentina. The Abaclat tribunal pointed out the alternatives - either Argentina would be involved in 60,000 proceedings with separate claimants adjudicated either by the same tribunal, or have each case decided by a different tribunal. But Abi-Saab was right when he wrote that the majority decided what was

\footnotetext{
${ }^{209}$ Abaclat Majority decision (n 60) 541.

210 ibid 542.

${ }^{211}$ Ambiente Ufficio Majority decision (n 61) 161.
} 
necessary for defence of Argentina's rights ${ }^{212}$ and what was advantageous for Argentina, which can by no means be accepted. This is not an issue to be decided by or to be assessed from a tribunal's perspective.

However, the proper question to ask is whether a tribunal may apply a "balancing of interests" test as it did in Abaclat. Does it matter that it would be arguably more difficult for Argentina to face 60,000 claims, for the purposes of deciding jurisdiction and admissibility of claims? The answer must be a resolute "no". Tribunals need to apply the law, and any potential problems for Argentina (assessed by the Abaclat tribunal, not Argentina!) cannot affect a decision on jurisdiction. And as a point of fact, Argentina opposed the "beneficial" solution of having all 60,000 claims decided in one class action proceeding by filing its preliminary objections.

It seems that the tribunal thought that it knew better what was in Argentina's interests. Balancing the interests of parties is clearly well beyond the powers of an ICSID tribunal. ${ }^{213}$ And it seems that the balancing of interests in the form it took in Abaclat has one main purpose - to enhance the protection granted to investors. Skilful sidestepping of procedural problems as it was, it cannot substitute for proper legal reasoning. The present author agrees that "the one-sidedness of this alleged balancing of interests is too glaring to need any further elaboration." 214

\section{Policy issues}

Procedural economy, efficient use of resources and avoidance of multiple proceedings are all clear advantages of dealing with bondholders' claims in one, instead of 60,000 separate cases. An avalanche of requests for arbitration of these proportions would obviously paralyse the ICSID.

Of course, a class action also has the undeniable advantage of allowing small claimants to coordinate their actions in order to bring a joint request for arbitration as a class and reduce the (mostly financial) obstacles that would be a deal-breaker for individual investors. An individual investor's claim may be so small that it would be impossible and financially unreasonable to initiate proceedings, taking into consideration the costs and potential net loss. ${ }^{215}$ However, one has to bear in mind that the bonds make no mention of ICSID as a forum for deciding disputes. Why, then, in those cases should the lack of availability of ICSID arbitration for an individual claimant be an argument in favour of mass claims proceedings? Individual bondholders should file their claims in the appropriate forum, here the domestic courts. ICSID is not a default forum to resolve those disputes and the Claimants had the option of exercising their constitutional right to due process of law in national courts.

It is true that class action helps to avoid the possibility of inconsistent and contradictory outcomes, which is a common problem with ICSID tribunals. For example, in some cases tribunals reached a different conclusion as to whether particular measures adopted by Argentina were justified because

\footnotetext{
${ }^{212}$ Abi-Saab Dissenting opinion (n 128) 243.

213 ibid 251.

214 ibid 260.

${ }^{215}$ Lamm, Pham, Meise Bay (n 51) 68.
} 
of the state of necessity. ${ }^{216}$ The problem of coherency matters even more when you consider that ICSID awards cannot be annulled by national courts, their enforcement is automatic and the national courts cannot deny $\mathrm{it}^{217}$.

However, all those advantages cannot outweigh the abovementioned problems or the lack of compatibility of mass claims with the ICSID system. The requirements imposed by international law are (or at least should be) always more important than speedy, efficient process and good use of resources.

\section{Conchusions}

Mass claims in investment arbitration sound like an oxymoron. Without any doubt the original concept of commercial and investment arbitration was to resolve disputes arising between two parties, not more. The unexpected evolution that we are facing at present is partially due to the Americanisation of international arbitration and the worldwide expansion of mass claims procedures that have their roots in the US.

Notwithstanding the deserved criticism of the Abaclat decision, the case will undoubtedly influence the manner in which BIT and arbitration clauses are drafted, and thus may serve to enhance certainty in investment arbitration. States will be more careful about tightening up the wording of provisions. On the other hand, the Abaclat ruling may encourage individual investors to coordinate their actions against states and bring mass claims in cases where the small values involved are ruled out by the high arbitration costs under ICSID arbitration. This might cause a flood of claims, which would be good for legal professionals, but not for states and their taxpayers, who ultimately have to pay out on awards.

The author shares Abi-Saab's objections to the majority interpretation in Abaclat of the ICSID Convention and BITs in a way that affords maximum protection to investment. ${ }^{218} \mathrm{He}$ was entirely correct in stating that "it is undermining the credibility not only of the ICSID system, but of the very idea of objective international adjudication, by eroding the confidence of states, whose consent remains the basis of jurisdiction." 219 It remains to be seen whether future tribunals pay due respect to those cornerstones of investment arbitration.

The conclusion that class action is allowed within the ICSID framework and that a tribunal merely has to fill in the gaps in the procedure by using Art. 19 of the ICSID Arbitration Rules and Art. 44 of the ICSID Convention must necessarily be regarded as a violation of the fundamental rule of procedure, which constitutes grounds for annulment of an award under Art. 52 (d) of the ICSID Convention.

\footnotetext{
${ }^{216}$ CMS Gas Transmission Co. v Argentine Republic, ICSID Case No. ARB/01/8, Award, May 12, 2005, (2005) 44 ILM 1205; LG\&E Energy Corp. v Argentine Republic, ICSID Case No. ARB/02/1, Decision on Liability, October 3, 2006, (2006) 21 ICSID Rev.-FILJ 269.

${ }^{217}$ Art. 54 of the ICSID Convention.

${ }^{218}$ Abi-Saab Dissenting opinion (n 128) 272.

219 ibid 274.
} 
In sum, in sidestepping jurisdictional criteria the majority decisions in both Abaclat and Ambiente Ufficio merit heavy criticism, and the investment arbitration world as a whole can only hope and pray that similar rulings will not be handed down in the future. Alemanni is undoubtedly a step in the right direction, at least when it comes to legal reasoning, and we can only wait to see which path will be chosen by subsequent mass claims tribunals. 